\title{
Protein recycling in growing rabbits: contribution of microbial lysine to amino acid metabolism
}

\author{
Álvaro Belenguer ${ }^{1}$, Joaquim Balcells ${ }^{1}$, Jose A. Guada ${ }^{1}$, Marc Decoux ${ }^{2}$ and Eric Milne ${ }^{3}$ \\ ${ }^{1}$ Departamento de Producción Animal y Ciencia de los Alimentos, Facultad de Veterinaria, Miguel Servet 177, Zaragoza 50013, Spain \\ ${ }^{2}$ Cargill, Paseig Sant Joan 193, Barcelona, Spain \\ ${ }^{3}$ Rowett Research Institute, Bucksburn, Aberdeen AB21 9SB, UK
}

(Received 1 August 2004 - Revised 19 April 2005 - Accepted 20 April 2005)

To study the absorption of microbial lysine in growing rabbits, a labelled diet (supplemented with ${ }^{15} \mathrm{NH}_{4} \mathrm{Cl}$ ) was administered to six animals (group ISOT); a control group (CTRL, four rabbits) received a similar, but unlabelled, diet. Diets were administered for $30 \mathrm{~d}$. An additional group of six animals were fed the unlabelled diet for $20 \mathrm{~d}$ and then the labelled diet for $10 \mathrm{~d}$ while wearing a neck collar to avoid caecotrophy (group COLL), in order to discriminate it from direct intestinal absorption. At day 30 animals were slaughtered and caecal bacteria and liver samples taken. The ${ }^{15} \mathrm{~N}$ enrichment in amino acids of caecal bacteria and liver were determined by GC-combustion/isotope ratio MS. Lysine showed a higher enrichment in caecal microflora ( 0.925 atom\% excess, APE) than liver ( 0.215 APE) in group ISOT animals, confirming the double origin of body lysine: microbial and dietary. The COLL group showed a much lower enrichment in tissue lysine (0.007 (SE 0.0029) APE for liver). Any enrichment in the latter animals was due to direct absorption of microbial lysine along the digestive tract, since recycling of microbial protein (caecotrophy) was avoided. In such conditions liver enrichment was low, indicating a small direct intestinal absorption. From the ratio of [ $\left.{ }^{15} \mathrm{~N}\right] \mathrm{lysine}$ enrichment between liver and bacteria the contribution of microbes to body lysine was estimated at $23 \%$, with $97 \%$ of this arising through caecotrophy. Absorption of microbial lysine through caecotrophy was 119 (SE 4.0) mg/d, compared with 406 (SE 1.8) mg/d available from the diet. This study confirms the importance of caecotrophy in rabbit nutrition ( $15 \%$ of total protein intake).

Rabbit: Caecotrophy: Microbial lysine: ${ }^{15} \mathrm{~N}$ kinetics

In herbivores, fibre must be digested symbiotically by gut microorganisms because they have not evolved cellulases, hemicellulases or pectinases. For this purpose host animals have developed specific gut compartments to optimise microbial growth conditions. Fermentation compartments can be located before (rumen; pre-gastric fermenters) or after the host enzyme digestion area (caecum/colon; post-gastric fermenters). Unlike for ruminants, in post-gastric fermenters the nutritional benefits of gut microflora are not clear. Absorption of microbial protein has been demonstrated in both pigs (Torrallardona et al. 2003a,b) and man (Metges et al. 1999), but whether this involves mechanisms before and/or after the ileum is uncertain.

Some caecum fermenters (i.e. lagomorphs) have developed a special system to re-ingest the products synthesised by microbes in the caecum. Called caecotrophy, this process consists of reingesting a special kind of faeces, caecotrophes or soft faeces, originating from the caecum where a selective retention of liquids and fine particles occurs (Hörnicke, 1981; Cheeke, 1987). Without a good quantitative estimation of this process, its nutritional impact creates uncertainty in lagomorph protein nutrition. This uncertainty is exacerbated by reports that in rats incorporation of microbial lysine into body protein relies entirely on coprophagy (Torrallardona et al. 1996b).
Lysine is an essential amino acid (EAA) that does not undergo transamination (Bender, 1985). This inability to transaminate is supported by isotopic studies in which ${ }^{15} \mathrm{~N}$ labelling in lysine was not found in germ-free rats after administration of inorganic ${ }^{15} \mathrm{~N}$ (Torrallardona et al. 1996a). In consequence, any $\left[{ }^{15} \mathrm{~N}\right]$ lysine in body tissues after administration of inorganic ${ }^{15} \mathrm{~N}$ sources should arise only through absorption of microbial lysine. In long-term isotope studies enrichment of body lysine must reflect the relative input of microbial and dietary lysine sources. Furthermore, whether such microbial lysine arises from direct absorption across the digestive tract (Marty \& Raynaud, 1965) or is first reingested by caecotrophy can be ascertained by fitting a neck collar to prevent caecotrophy.

The first aim of the present study was to establish how much body lysine comes from both sources, microbes and food, in growing rabbits; the second was to determine whether microbial lysine incorporated into tissues comes entirely from caecotrophy.

\section{Materials and methods}

Animals

Sixteen growing New Zealand White male rabbits, weaned at $35 \mathrm{~d}$ of age, were used. Average initial body weight was $1 \cdot 127$ (SE 0.0395) 
$\mathrm{kg}$, and the animals were $45 \mathrm{~d}$ old. Animals were penned individually in $64 \mathrm{~cm} \times 44 \mathrm{~cm} \times 32 \mathrm{~cm}$ cages during the adaptation period and kept in metabolism cages $(44 \mathrm{~cm} \times 44 \mathrm{~cm} \times 32 \mathrm{~cm})$ for urine and faeces collection, always under a constant light cycle (08.0020.00 hours) and with free access to drinking water. Temperature and humidity were controlled at a constant level of $18-24^{\circ} \mathrm{C}$ and less than $20 \%$, respectively.

\section{Diets}

The basal diet (Table 1) was formulated based on grass hay (35\%), barley grain $(25 \%)$, sugarbeet pulp (20\%), soyabean meal (15.5\%) and sunflower oil, either supplemented or not with ${ }^{15} \mathrm{NH}_{4} \mathrm{Cl}$ powder $\left(1 \%, 10+\right.$ atom $\%{ }^{15} \mathrm{~N}$; ISOTEC Inc., Miamisburg, OH, USA). Diet was administered in pellet form $(3 \mathrm{~mm} \varnothing)$. Animals were fed once daily at a restricted level ( $100 \mathrm{~g}$ fresh matter/d or $570 \mathrm{~kJ}$ dietary energy $/ \mathrm{kg}$ weight ${ }^{075}$ ) and the feed was sampled weekly. The average daily ${ }^{15} \mathrm{~N}$ dose consumed was $24.4 \mathrm{mg}$ by ISOT rabbits and $19 \cdot 3 \mathrm{mg}$ by COLL rabbits.

\section{Experimental design}

Three experimental treatments were imposed during a $30 \mathrm{~d}$ period (rabbits 50 to $80 \mathrm{~d}$ old):

(1) In treatment 1 (isotope group (ISOT), six animals), rabbits were fed the isotope-supplemented diet during the whole experimental period;

(2) In treatment 2 (isotope-collar group (COLL), six animals), rabbits received the unlabelled diet for $20 \mathrm{~d}$. On day 21 these animals were fitted with a flat wooden collar $(50 \mathrm{~mm}$ inner diameter, $250 \mathrm{~mm}$ outer diameter, weighing approximately $65 \mathrm{~g}$ ) and fed the isotope-supplemented diet from day 21 to $30(10 \mathrm{~d})$;

(3) In the control group (CTRL, four animals), rabbits were fed only the unlabelled diet during the whole experimental period (Fig. 1).

Table 1. Ingredients and chemical composition of the experimental diets

\begin{tabular}{|c|c|c|}
\hline & Unlabelled diet & Labelled diet \\
\hline \multicolumn{3}{|l|}{ Ingredient (g/kg) } \\
\hline Barley grain & 250 & 252 \\
\hline Soyabean meal & 156 & 155 \\
\hline Gramineous hay & 353 & 350 \\
\hline Sugarbeet pulp & 200 & 198 \\
\hline Sunflower oil & 40 & 33 \\
\hline Vitamin-mineral mix ${ }^{*}$ & 1 & 2 \\
\hline${ }^{15} \mathrm{NH}_{4} \mathrm{Cl}$ & - & 10 \\
\hline \multicolumn{3}{|c|}{ Chemical composition (g/kg) } \\
\hline Dry matter & 942.5 & $931 \cdot 3$ \\
\hline Organic matter & $922 \cdot 4$ & $922 \cdot 2$ \\
\hline $\mathrm{N}$ & $27 \cdot 9$ & $30.8 \dagger$ \\
\hline Neutral detergent fibre & $297 \cdot 0$ & $320 \cdot 5$ \\
\hline Acid detergent fibre & $158 \cdot 4$ & $165 \cdot 4$ \\
\hline Acid detergent lignin & $23 \cdot 3$ & $20 \cdot 4$ \\
\hline \multicolumn{3}{|c|}{$\begin{array}{l}{ }^{*} \text { Composition of vitamin-mineral mix: } 200 \mathrm{ppm} \mathrm{Co}\left(\mathrm{CoSO}_{4} \cdot 7 \mathrm{H}_{2} \mathrm{O}\right) \text {, } \\
3000 \mathrm{ppm} \mathrm{Cu}\left(\mathrm{CuSO}_{4} \cdot 5 \mathrm{H}_{2} \mathrm{O}\right), 20000 \mathrm{ppm} \mathrm{Fe}\left(\mathrm{FeSO}_{4} \cdot \mathrm{H}_{2} \mathrm{O}\right), 8000 \mathrm{ppm} \\
\mathrm{Mn}\left(\mathrm{MnO}_{2}\right), 30000 \mathrm{ppm} \mathrm{Zn}(\mathrm{ZnO}), 30 \mathrm{ppm} \mathrm{Se}\left(\mathrm{Na}_{2} \mathrm{SeO}_{3}\right), 500 \mathrm{ppm} \text { I } \\
(\mathrm{KI}), 4500000 \mathrm{IU} \text { vitamin } \mathrm{A} / \mathrm{kg}, 550000 \mathrm{IU} \text { vitamin } \mathrm{D}_{3} / \mathrm{kg}, 1100 \mathrm{ppm} \text { vita- } \\
\text { min } \mathrm{E}, 250 \mathrm{ppm} \text { vitamin } \mathrm{B}_{1}, 1500 \mathrm{ppm} \text { vitamin } \mathrm{B}_{2}, 100 \mathrm{ppm} \text { vitamin } \mathrm{B}_{6} \text {, } \\
6000 \mathrm{ppm} \text { vitamin } \mathrm{B}_{12}, 500 \mathrm{ppm} \text { vitamin } \mathrm{K}, 5000 \mathrm{ppm} \text { D-pantothenate, } \\
12500 \mathrm{ppm} \text { niacin, } 100000 \mathrm{ppm} \text { choline chloride. } \\
\text { †2.7 g N comes from the supplement }\left({ }^{15} \mathrm{NH}_{4} \mathrm{Cl}\right) \text {. }\end{array}$} \\
\hline
\end{tabular}

Due to the number of metabolic crates available (eight), rabbits were subdivided in two groups of eight animals each, including three rabbits from ISOT and COLL and two from the CTRL group. Additionally, temporary neck collars were fitted for $12 \mathrm{~h}$ approximately every $6 \mathrm{~d}$ to rabbits in the ISOT group in order to collect caecotrophes, extract bacteria from them and check

${ }^{15} \mathrm{~N}$ enrichment in lysine of these microbes (Fig. 1).

\section{Measurements and sampling}

All animals were slaughtered at $80 \mathrm{~d}$ of age between 08.00 and 12.00 hours. Animals were killed by cervical dislocation and dissected, the caecum excised and weighed, and caecal contents sampled $(20-50 \mathrm{~g})$. The samples were diluted in methylcellulose solution $(9 \mathrm{~g} \mathrm{NaCl} / 1,1 \mathrm{~g}$ methylcellulose $/ \mathrm{l})$ and chilled at $4^{\circ} \mathrm{C}$ for $24 \mathrm{~h}$ to dislodge adherent bacteria (Minato \& Suto, 1978). After shaking, bacteria were isolated from the solution by differential centrifugation ( $500 \mathrm{~g}$ for $5 \mathrm{~min}$; followed by two consecutive centrifugations of the supernatant at $20000 \mathrm{~g}$ for $20 \mathrm{~min}$ at $4^{\circ} \mathrm{C}$ ). The resultant microbial pellet was freeze-dried for subsequent analysis. The same technique was used to obtain the microbial extract from caecotrophes collected from the ISOT group. After removal of the gastrointestinal tract, liver and muscle (semitendinosis) were sampled and the carcass was frozen. Later, the carcass was partially thawed, and then sawn into several parts. The segments were ground and mixed thoroughly before sampling. All the samples were frozen and freeze-dried until further analysis.

\section{Analytical procedures}

$\mathrm{DM}$ in food and faeces was determined by drying at $60^{\circ} \mathrm{C}$ to constant weight. Organic matter was estimated by ashing samples at $550^{\circ} \mathrm{C}$ for $8 \mathrm{~h}$. N was measured by the Kjeldahl method. Neutral detergent fibre, acid detergent fibre and acid detergent lignin were determined according to Van Soest et al. (1991), after amylase pretreatment. Finally freeze-dried (extracted bacteria, liver, muscle and carcass) samples were ground in a coffee grinder for further analysis. Ground freeze-dried samples were dried at $100^{\circ} \mathrm{C}$ for $24 \mathrm{~h}$ to determine their residual water content.

Amino acid (AA) composition was determined by HPLC using the Waters Pico-Tag method, which involves pre-column derivatisation with phenylisothiocyanate (Cohen et al. 1989). Protein hydrolysis was performed in distilled constant boiling $5.6 \mathrm{M}$ $\mathrm{HCl}$ in sealed, evacuated tubes at $110^{\circ} \mathrm{C}$ for $24 \mathrm{~h}$. Oxidation with performic acid was not carried out, hence presented values of methionine may be underestimated.

Microbial samples, caecotrophes and freeze-dried liver (approximately $0.4 \mathrm{mg}$ lysine from each substrate) were hydrolysed with distilled constant boiling $5.6 \mathrm{M}-\mathrm{HCl}\left(110^{\circ} \mathrm{C}\right.$ for $\left.18 \mathrm{~h}\right)$ in sealed tubes. Samples were filtered through a $0.2 \mu \mathrm{m}$ pore size filter and dried in a rotary evaporator. Then, they were desalted by ion-exchange chromatography (AG 50W-X8 resin, $\mathrm{H}^{+}$form; Bio-Rad, Hercules, CA, USA), and all AA eluted with $2 \mathrm{M}-\mathrm{NH}_{4} \mathrm{OH}$. The samples were frozen and then freezedried. Sample concentrations were adjusted to $3 \mathrm{~mm}$ with regard to lysine and then converted to their t-butyldimethylsilyl derivatives prior to analysis by GC-combustion/isotope ratio MS. The derivatised AA mixture $(1 \mu \mathrm{l})$ was injected in splitless mode onto a Trace gas chromatograph, interfaced to a GC Combustion III unit on a ThermoFinnigan Delta ${ }^{\text {plus }}$ XL mass spectrometer (ThermoFinnigan, Bremen, Germany). The combustion 


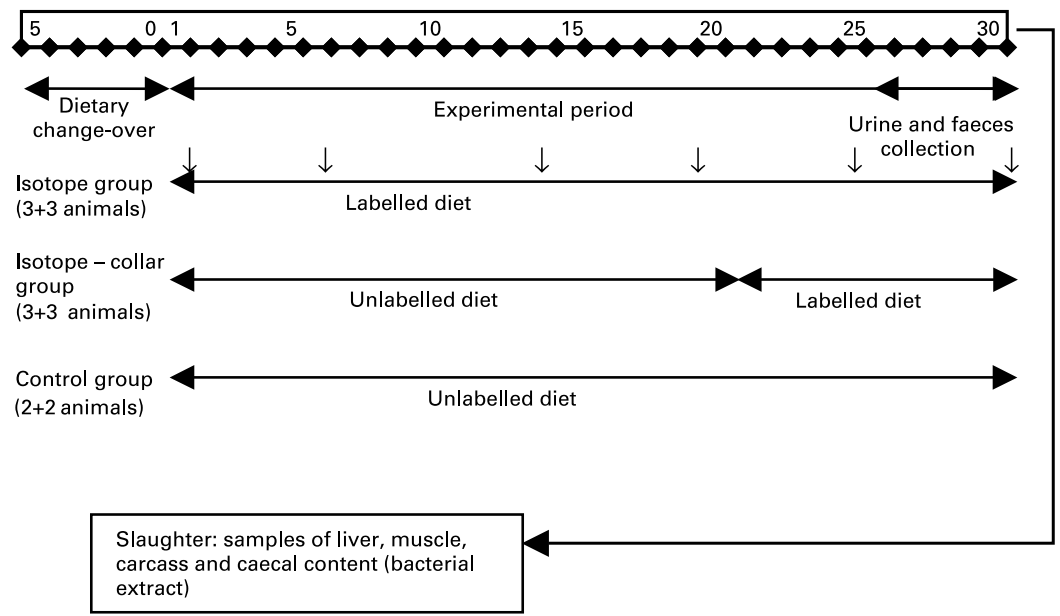

Fig. 1. Schematic illustration of the experimental protocol and treatments used in the experimental design. In the isotope group, $\downarrow$ indicates when temporary neck collars were fitted in order to collect caecotrophes and check the time course of ${ }^{15} \mathrm{~N}$ enrichment in bacterial lysine.

interface oxidises the individual separated $\mathrm{AA}$ as they elute from the gas chromatograph. Oxidation was achieved at $980^{\circ} \mathrm{C}$ using $\mathrm{Cu}, \mathrm{Pt}$ and $\mathrm{Ni}$ wires. The nitrogen oxides produced during this process were reduced to $\mathrm{N}_{2}$ at $650^{\circ} \mathrm{C}$ using $\mathrm{Cu}$ wires. Water of combustion was removed using a Nafion membrane. Finally, liquid $\mathrm{N}_{2}$ was used to remove $\mathrm{CO}_{2}$ and the resulting pure $\mathrm{N}_{2}$ gas was admitted to the mass spectrometer. The ratio of $\mathrm{m} / \mathrm{z}$ 28:29 was measured and compared with reference, $\mathrm{O}_{2}$-free $\mathrm{N}_{2}$ gas.

\section{Calculations}

The contribution of total microbial lysine $\left(\mathrm{M}_{\mathrm{lys}}(\mathrm{Tot})\right)$, and that from absorption along the digestive tract prior to caecotrophy (direct intestinal absorption; $\mathrm{M}_{\mathrm{lys}}(\mathrm{Int})$ ) and through the caecotrophy process $\left(\mathrm{M}_{\mathrm{lys}}(\mathrm{Cec})\right)$, to tissue lysine was estimated as:

$$
\begin{aligned}
& \mathrm{M}_{\text {lys }}(\text { Tot })=\mathrm{E}_{\text {LivlSOT }} / \mathrm{E}_{\text {bacISOT, }} \\
& \mathrm{M}_{\text {lys }}(\text { Int })=\mathrm{E}_{\text {LivCOLL }} / \mathrm{E}_{\text {bacISOT }}
\end{aligned}
$$

and

$$
\mathrm{M}_{\mathrm{lys}}(\mathrm{Cec})=\left[1-\left(\mathrm{M}_{\mathrm{lys}}(\mathrm{Int}) / \mathrm{M}_{\mathrm{lys}}(\mathrm{Tot})\right)\right] \times \mathrm{M}_{\mathrm{lys}}(\mathrm{Tot}),
$$

where $\mathrm{E}_{\text {Livisot }}$ is the $\left[{ }^{15} \mathrm{~N}\right]$ lysine enrichment (atom\% excess, APE) in liver and $\mathrm{E}_{\text {bacISOT }}$ that in caecal bacteria in ISOT animals, and $\mathrm{E}_{\text {LivCOLL }}$ is the $\left[{ }^{15} \mathrm{~N}\right]$ lysine enrichment (APE) in liver of those animals wearing the collar (COLL). Substrate enrichment (E, APE) was calculated as the difference between the induced abundance $\left(\mathrm{Ab}\right.$, atom\%) and the background ${ }^{15} \mathrm{~N}$ abundance of each substrate (obtained from CTRL animals: $\left.\mathrm{E}_{\mathrm{Liv}}=\mathrm{A} b_{\text {Liv }}-\mathrm{Ab}_{\text {LivCTRL) }}\right)$.

This approach assumes that bacterial and liver protein enrichments have reached near plateaux. Tissue protein synthesis involves use of free EAA from three sources: dietary, released from protein turnover (degradation) and those from microbial origin. In short-term isotope treatments, unlabelled lysine can arise from both the diet and protein degradation. In longer-term studies, however, the tissue protein attains a plateau and this represents the labelled:unlabelled inflows from bacteria:diet (i.e. the lysine from protein degradation is released at this same ratio).
Absorbed microbial lysine derived from caecotrophy $\left(\mathrm{M}_{\mathrm{lysA}}\right)$ was calculated as follows:

$$
\mathrm{M}_{\mathrm{lysA}}=\left(\mathrm{M}_{\mathrm{lys}}(\mathrm{Cec}) \times \mathrm{D}_{\mathrm{lysA}}\right) /\left(1-\mathrm{M}_{\mathrm{lys}}(\mathrm{Cec})-\mathrm{M}_{\mathrm{lys}}(\mathrm{Int})\right),
$$

where $\mathrm{M}_{\mathrm{lys}}(\mathrm{Cec})$ and $\mathrm{M}_{\mathrm{lys}}(\mathrm{Int})$ are the respective contributions of microbial lysine from caecotrophy and intestinal absorption to tissue lysine, while $\mathrm{D}_{\text {lys }}$ is the dietary supply of absorbed lysine, estimated by assuming a true ileal digestibility of 0.8 (Carabaño et al. 2000).

\section{Statistical analysis}

Data were analysed as one-way classification with unequal replication per treatment. Animals were considered as a random variable and the analysis was performed using the MIXED MODEL procedure in SAS version 8, 1999 (SAS Institute Inc., Cary, NC, USA). Significance was taken as $P<0 \cdot 05$. The isotopic enrichment of AA in the liver protein of the rabbits was compared with their corresponding background by Student's paired $t$ test.

\section{Results}

All animals remained in good health throughout the experimental period. They adapted well to the experimental diets and neither mortality nor morbidity problems were observed. Therefore all individuals were considered in the statistical analysis.

\section{Feed intake and body weight changes}

Animals were randomly allocated to groups, and therefore no differences in initial weight $(1.127$ (SE 0.0395) $\mathrm{kg} ; P=0.739)$ were observed (Table 2). Although food supply was restricted, animals fitted with the neck collar (COLL) showed a lower DM intake $(72.73 \mathrm{~g} / \mathrm{d})$ and a greater variability $(\mathrm{CV}=23.1 \%)$, but no differences were observed between treatments ISOT and CTRL (91.89 and $93.33 \mathrm{~g} / \mathrm{d}$, respectively) and their CV were much lower (1.11 and $0.72 \%$ for ISOT and CTRL, respectively). The lower intake by COLL rabbits was reflected in a decrease in growth rate $(-23.4 \% ; P=0.008)$ and final weight $(-15.9 \%$; $P=0.033$ ) compared with the other two groups (Table 2 ). 
Table 2. Feed intake and body weight change of rabbits between 45 and $80 \mathrm{~d}$ of age fed the ${ }^{15} \mathrm{NH}_{4} \mathrm{Cl}$-supplemented diet (isotope group: ISOT), the non-supplemented diet (control group: CTRL) and the supplemented diet while wearing a neck collar (isotope-collar group: COLL)

(Mean values with standard error of the treatment means)

\begin{tabular}{|c|c|c|c|c|c|}
\hline & $\begin{array}{l}\text { ISOT } \\
(n 6)\end{array}$ & $\begin{array}{c}\text { CTRL } \\
(n 4)\end{array}$ & $\begin{array}{c}\text { COLL } \\
(n 6)\end{array}$ & SE & $P$ value \\
\hline Initial weight $(\mathrm{kg})$ & $1 \cdot 163$ & $1 \cdot 130$ & 1.088 & 0.0730 & 0.739 \\
\hline Final weight (kg) & $2 \cdot 194^{\mathrm{a}}$ & $2 \cdot 237^{\mathrm{a}}$ & $1.859^{b}$ & 0.1010 & 0.033 \\
\hline Feed intake (g DM/d) & $91 \cdot 89^{\mathrm{a}}$ & $93.33^{a}$ & $72 \cdot 73^{\mathrm{b}}$ & $4 \cdot 601$ & 0.010 \\
\hline Growth rate $(\mathrm{g} / \mathrm{d})$ & $30 \cdot 4^{a}$ & $32 \cdot 8^{\mathrm{a}}$ & $24 \cdot 0^{\mathrm{b}}$ & 1.702 & 0.008 \\
\hline
\end{tabular}

${ }^{a, b}$ Mean values within a row with unlike superscript letters were significantly different $(P$ value indicated in the last column).

\section{Amino acid composition of diet, tissue and bacterial protein}

Total AA content $(\mathrm{g} / \mathrm{kg} \mathrm{DM})$ was lower in food than in carcass or caecal bacteria (Table 3). Also, the concentration of both total AA and lysine was significantly higher $(P=0.002$ and $P=0.014$, respectively) in muscle than in the whole carcass. Similarly, the values were greater in caecal bacteria compared with caecotrophes $(P=0.003$ and $P=0.033$, respectively). Lysine contribution to the total AA analysed was different depending on the substrate $(P=0 \cdot 0004)$, being lower in food $(4.13$ (SE 0.400)\%) than in caecotrophes $(6.39$ (SE 0.087)\%), caecal bacteria $(6.59$ (SE 0.164)\%), carcass $(6.71$ (SE 0.292)\%) and muscle (7.85 (SE $0.639) \%$, where the highest proportion was recorded. Differences existed in the pattern of AA ( $\mathrm{g} \mathrm{AA} / 100 \mathrm{~g}$ total AA) between bacteria and caecotrophes, with tyrosine and methionine being higher ( $P=0.004$ and $P=0.02$, respectively) and threonine and proline lower $(P=0.02$ and $P=0.007$, respectively) in the former.

\section{${ }^{15} \mathrm{~N}$ enrichments in amino acids}

The time course of $\left[{ }^{15} \mathrm{~N}\right]$ lysine enrichment in bacteria extracted from caecotrophes of the ISOT group shows that, for practical purposes, the ${ }^{15} \mathrm{~N}$ enrichment plateau was reached after $10 \mathrm{~d}$ (Fig. 2).

Table 4 shows the $\left[{ }^{15} \mathrm{~N}\right] l y$ sine enrichments in liver and bacteria from caecotrophes in rabbits receiving ISOT treatment, and in liver and caecotrophes of COLL animals. The isotope abundance in liver (0.372 (SE 0.0007) atom\%) of the CRTL animals consuming the non-isotope diet and the abundance in bacteria extracted initially (day 0) from ISOT animals (0.374 (SE 0.0015) atom\%) were taken as background for liver and bacteria or caecotrophes, respectively. Rabbits in the ISOT group, which received the isotope-labelled diet, showed significant increases $(P<0.001)$ in isotope enrichments in lysine for both caecal bacteria (0.925 (SE $0.0313)$ APE) and liver (0.215 (SE 0.0089) APE). The isotopic enrichment of liver was 0.233 (SE 0.0057) of that observed in caecal bacteria. In COLL rabbits, which were also fed the isotope-labelled diet but without caecotrophy, bacterial enrichment was not determined due to the small amount of available sample. Lysine of caecotrophes showed a lower ${ }^{15} \mathrm{~N}$ enrichment (0.759 (SE 0.0285) APE; $P=0.005$ ) compared with bacteria of treatment ISOT, due to dilution with the endogenous lysine of the mucous envelope. These rabbits, however, showed much lower $(P<0.001)$ liver enrichments in lysine $(0.007$ (SE 0.0029) APE), which still tended to be different from background when analysed by Student's paired $t$ test $(P=0 \cdot 07)$.

Table 5 shows the enrichment in other essential and non-essential AA. Most AA analysed, except proline, showed enrichments close to $0.9-1.0$ in microbes and close to $0.8-0.9$ in caecotrophes. As for lysine, enrichment in most AA, except proline $(P=0.222)$, was higher in bacteria than in caecotrophes (alanine, serine, aspartate, glutamate, tyrosine, valine, leucine, threonine, phenylalanine $(P<0 \cdot 05)$, glycine and isoleucine $(P<0 \cdot 01))$. Non-essential AA (except proline) reached higher enrichments in liver of ISOT animals compared with COLL animals, with the latter being much lower in EAA, although still significant. Some AA are not shown in the table due to the poor resolution of their integration peak.

Table 3. Amino acid (AA) composition ( $\mathrm{g} / \mathrm{kg} \mathrm{DM}$ ) of the diet, body tissues including muscle and milled carcass, and caecal components including caecal bacteria and caecotrophes

(Mean values with their standard error)

\begin{tabular}{|c|c|c|c|c|c|c|c|c|c|c|}
\hline \multirow[b]{3}{*}{ AA (g/kg DM) } & \multicolumn{6}{|c|}{ Body tissues } & \multicolumn{4}{|c|}{ Caecal components } \\
\hline & \multicolumn{2}{|c|}{ Diet $(n 4)$} & \multicolumn{2}{|c|}{ Muscle (n 6) } & \multicolumn{2}{|c|}{ Carcass (n 6) } & \multicolumn{2}{|c|}{$\begin{array}{c}\text { Caecal bacteria } \\
(n 5)\end{array}$} & \multicolumn{2}{|c|}{$\begin{array}{l}\text { Caecotrophes } \\
\qquad(n 5)\end{array}$} \\
\hline & Mean & SE & Mean & SE & Mean & SE & Mean & $\mathrm{SE}$ & Mean & SE \\
\hline Lysine & 5.5 & 0.7 & $48 \cdot 2$ & $5 \cdot 1$ & 31.9 & 1.6 & $25 \cdot 9$ & 1.5 & $18 \cdot 8$ & 0.9 \\
\hline Aspartic acid & $13 \cdot 2$ & 1.5 & $77 \cdot 7$ & $6 \cdot 8$ & $75 \cdot 8$ & $5 \cdot 6$ & $52 \cdot 3$ & $4 \cdot 7$ & $38 \cdot 3$ & 1.9 \\
\hline Glutamic acid & $27 \cdot 7$ & $1 \cdot 1$ & $135 \cdot 6$ & $12 \cdot 0$ & $126 \cdot 6$ & 4.8 & $63 \cdot 8$ & 2.5 & $47 \cdot 6$ & $2 \cdot 4$ \\
\hline Serine & $6 \cdot 8$ & 0.3 & $26 \cdot 0$ & 1.4 & $22 \cdot 0$ & 0.8 & $18 \cdot 8$ & 0.7 & $14 \cdot 6$ & 0.9 \\
\hline Glycine & $7 \cdot 0$ & 0.4 & 31.5 & $1 \cdot 3$ & $33 \cdot 6$ & 1.7 & $21 \cdot 6$ & $1 \cdot 2$ & $16 \cdot 4$ & 0.7 \\
\hline Histidine & 3.8 & 0.3 & $26 \cdot 5$ & 1.8 & $18 \cdot 8$ & 0.8 & $6 \cdot 1$ & 0.2 & 4.8 & 0.3 \\
\hline Arginine & $9 \cdot 0$ & $1 \cdot 1$ & $40 \cdot 2$ & $3 \cdot 3$ & $26 \cdot 0$ & 1.0 & $18 \cdot 2$ & 1.2 & $12 \cdot 4$ & 0.8 \\
\hline Threonine & $7 \cdot 0$ & 0.4 & $29 \cdot 1$ & 1.4 & $22 \cdot 4$ & 0.9 & $24 \cdot 4$ & $1 \cdot 2$ & $19 \cdot 7$ & 1.0 \\
\hline Alanine & 6.6 & 0.5 & 38.0 & 3.5 & $36 \cdot 0$ & 1.6 & $25 \cdot 4$ & 1.8 & $18 \cdot 1$ & 1.0 \\
\hline Proline & $10 \cdot 3$ & 0.5 & $22 \cdot 0$ & $2 \cdot 2$ & $6 \cdot 3$ & 1.4 & $15 \cdot 6$ & 1.7 & $15 \cdot 6$ & 0.7 \\
\hline Tyrosine & $5 \cdot 8$ & 0.3 & 22.4 & 2.0 & 1.0 & 0.5 & $21 \cdot 6$ & 1.0 & $15 \cdot 0$ & 0.9 \\
\hline Valine & $6 \cdot 8$ & 0.5 & $25 \cdot 6$ & 2.5 & $16 \cdot 1$ & 0.5 & $23 \cdot 4$ & 1.8 & $17 \cdot 8$ & $1 \cdot 1$ \\
\hline Methionine & $2 \cdot 2$ & 0.1 & $17 \cdot 6$ & 1.5 & 11.5 & 0.3 & $10 \cdot 6$ & 0.6 & 6.9 & 0.4 \\
\hline Isoleucine & $5 \cdot 1$ & 0.4 & $24 \cdot 4$ & 2.9 & 14.0 & 0.6 & $20 \cdot 1$ & 1.5 & $15 \cdot 1$ & 0.9 \\
\hline Leucine & $9 \cdot 0$ & 0.5 & $39 \cdot 2$ & 4.4 & $24 \cdot 2$ & 0.9 & $26 \cdot 6$ & $2 \cdot 1$ & $20 \cdot 2$ & 1.3 \\
\hline Phenylalanine & 7.0 & 0.6 & 21.4 & $2 \cdot 8$ & $12 \cdot 4$ & 0.6 & $18 \cdot 1$ & $1 \cdot 3$ & $13 \cdot 7$ & 0.7 \\
\hline Sum of $A A$ & 133.01 & 5.66 & 610.47 & 29.03 & 476.00 & $13 \cdot 88$ & 392.39 & $18 \cdot 73$ & 295.04 & 13.65 \\
\hline
\end{tabular}




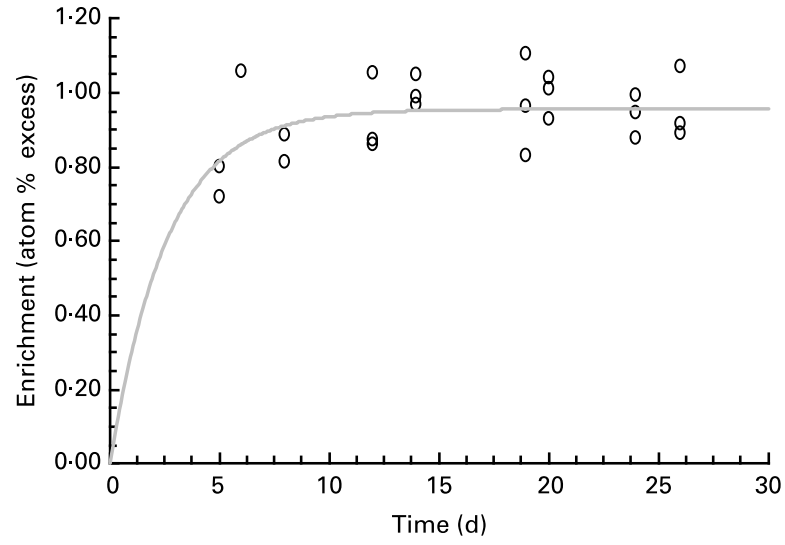

Fig. 2. Time course of the ${ }^{15} \mathrm{~N}$ enrichment (atom \% excess) in bacterial lysine from animals receiving the isotope-enriched diet (ISOT group).

\section{Estimates of microbial lysine absorption}

The contribution of microbial lysine to total absorption was 0.233 (SE 0.0057) and represented about one-quarter of total absorbed lysine, corresponding mostly to the caecotrophy process $(97 \%)$ and only $3 \%$ to direct intestinal absorption (Table 6). Ingestion of dietary lysine was calculated based on AA composition (Table 3) and individual DM intake (Table 2). Lysine absorption was estimated by assuming a true digestibility for dietary lysine of $0 \cdot 8$ (Carabaño et al. 2000).

\section{Discussion}

\section{Enrichment of amino acid-nitrogen in bacteria and tissues}

Initially, when the experiment was planned, we considered that the $\mathrm{N}$ requirements of the microbial population in the digestive tract would be met mostly by recycled blood urea-N and endogenous N (Forsythe \& Parker, 1985), while dietary non-digestible

Table 4. ${ }^{15} \mathrm{~N}$ enrichment (atom\% excess) of lysine in liver and caecal bacteria or caecotrophes of rabbits fed the ${ }^{15} \mathrm{NH}_{4} \mathrm{Cl}$-supplemented diet without (isotope group: ISOT) or with a neck collar fitted (isotope-collar group: COLL)

\begin{tabular}{lrccc}
\hline & Animal & Liver & Caecal bacteria* $^{*}$ & Caecotrophes \\
\hline ISOT & 1 & 0.205 & 0.926 & - \\
& 2 & 0.193 & 0.857 & - \\
& 3 & 0.226 & 0.878 & - \\
& 4 & 0.198 & 0.894 & - \\
& 5 & 0.252 & 1.072 & - \\
\multirow{4}{*}{ COLL } & 6 & 0.218 & 0.920 & - \\
& Mean & 0.215 & 0.925 & - \\
& SE & 0.0089 & 0.0313 & 0.742 \\
& 7 & - & - & 0.764 \\
& 8 & 0.016 & - & 0.849 \\
& 9 & 0.001 & - & - \\
& 10 & 0.004 & - & 0.783 \\
& 11 & 0.003 & - & 0.759 \\
& 12 & 0.012 & - & 0.0285 \\
& Mean & 0.007 & - & \\
\hline
\end{tabular}

*Bacteria extracted from caecotrophes at the end of the experiment.

† Statistical significance of the difference between the average enrichment in each group. protein would make a minor contribution. This moved us to attempt to label the blood urea pool by supplying sufficient ${ }^{15} \mathrm{~N}$ in the form of ${ }^{15} \mathrm{NH}_{4} \mathrm{Cl}$ in the diet. Fig. 2 shows that this objective was clearly achieved. Bacteria extracted from caecotrophes were appropriately enriched with ${ }^{15} \mathrm{~N}$ and within $10 \mathrm{~d}$ of starting isotope administration, total microbial $\mathrm{N}$ and lysine- $\mathrm{N}$ enrichment had almost reached a plateau (Fig. 2). We assumed that the enrichment obtained in bacteria extracted from caecotrophes is similar to the enrichment in bacteria colonising the caecum, based on the fact that caecotrophes originate in the caecum and so bacterial composition should be similar in both substrates as suggested by Emaldi et al. (1979), who found a similar cellulolytic flora, and by Jehl et al. (1996), who described no difference in bacterial fibrolityc activity. Isotopic enrichment of bacterial $\mathrm{N}$ in ISOT animals averaged 1.0 (SE 0.03) APE at the end of the experiment, similar to the enrichment recorded in microbial lysine-N (0.925 (SE 0.0313) APE). Moreover, after $30 \mathrm{~d}$ we can assume that lysine was equilibrated into body pools. Liver protein has a high fractional synthesis rate $(0 \cdot 154-0 \cdot 317 / \mathrm{d}$; Nicholas et al. 1977) and a short half-life $(2-5 \mathrm{~d})$. Equilibration with isotope needs to occur for a sufficient time for all lysine released from protein degradation to enter the body free lysine pool at similar enrichment. Then, the isotopic enrichment of tissue protein lysine would depend on the input ratio between ${ }^{15} \mathrm{~N}$-labelled and non-labelled lysine. Non-labelled lysine comes from diet, whereas ${ }^{15} \mathrm{~N}$-labelled lysine is provided by microbes. Although recycling of lysine in tissues exists, when isotope equilibrium in the metabolic $\mathrm{N}$ pool has been achieved, the enrichment ratio between tissue and microbial lysine will reflect the microbial contribution to body lysine. Isotope administration time in the COLL group was shorter (10 d), in order to reduce the stress of wearing the collar. However, based on the short half-life of lysine in liver $(2-5 \mathrm{~d})$ enrichment of protein in this tissue will be close to body free lysine and will give a reasonable estimate of the relative contributions of microbial and dietary inflows. Slow-turnover tissues, such as muscle, make a relatively small contribution to whole-body lysine flux (Lobley et al. 1980) and thus non-attainment of plateau for these tissues will have a minor impact.

The question is whether bacterial lysine is available to the animal and, if so, by what route? COLL animals showed a lower lysine enrichment in caecotrophes than did bacteria extracted from caecotrophes in ISOT animals $(0.759$ v. 0.925 APE for COLL and ISOT, respectively). During soft faeces excretion, caecal digesta pass through the gut without great changes and are incorporated in soft faeces or caecotrophes. But, in the distal colon, caecotrophes are covered with a mucous envelope which contains endogenous AA (Fraga, 1988). This explains the lower AA enrichment observed in the caecotrophes of animals of the COLL group. Consequently, based on both the rapid attainment of plateau and the lack of differences in total $\mathrm{N}$ enrichment, determined by isotope ratio MS, between caecal bacteria extracted from ISOT and COLL animals $(0.853$ and 0.889 for ISOT and COLL animals, respectively; $P=0.662$; data not presented), we assumed that bacteria in COLL animals would have similar enrichments to those in ISOT animals, and this is why we used the latter values for the calculations of microbial contribution to tissue lysine by direct intestinal absorption. The collar reduced liver lysine enrichment to 0.007 APE and thus the possible impact of our assumption on the real value for direct gut incorporation was minimised. The collar prevented isotope incorporation into body lysine via caecotrophy and liver 
Table 5. ${ }^{15} \mathrm{~N}$ enrichment (atom\% excess) in amino acids of liver and caecal bacteria or caecotrophes of rabbits fed the ${ }^{15} \mathrm{NH}_{4} \mathrm{Cl}$-supplemented diet without (isotope group: ISOT) or with a neck collar fitted (isotope-collar group: COLL)

(Mean values with their standard error)

\begin{tabular}{|c|c|c|c|c|c|c|c|c|c|}
\hline \multirow[b]{3}{*}{ Amino acids } & \multicolumn{4}{|c|}{ ISOT } & \multicolumn{4}{|c|}{ COLL } & \multirow[b]{3}{*}{$P$ valuet } \\
\hline & \multicolumn{2}{|c|}{ Caecal bacteria* $(n 6)$} & \multicolumn{2}{|c|}{ Liver $(n 6)$} & \multicolumn{2}{|c|}{ Caecotrophes ( $n$ 5) } & \multicolumn{2}{|c|}{ Liver ( $n$ 4) } & \\
\hline & Mean & SE & Mean & SE & Mean & SE & Mean & SE & \\
\hline \multicolumn{10}{|l|}{ Non-essential } \\
\hline Alanine & 1.032 & 0.0227 & 0.905 & 0.0166 & 0.929 & 0.0269 & 0.662 & 0.0504 & 0.026 \\
\hline Glycine & 0.819 & 0.0233 & 0.768 & 0.0210 & 0.748 & 0.0227 & 0.407 & 0.0173 & 0.084 \\
\hline Proline & 0.424 & 0.0330 & 0.206 & 0.0077 & 0.355 & 0.0294 & 0.072 & 0.0033 & 0.222 \\
\hline Serine & 0.923 & 0.0360 & 0.641 & 0.0186 & 0.760 & 0.0301 & 0.442 & 0.0547 & 0.013 \\
\hline Aspartate & 1.079 & 0.0277 & 0.730 & 0.0112 & 0.922 & 0.0278 & 0.489 & 0.0377 & 0.006 \\
\hline Glutamate & $1 \cdot 137$ & 0.0263 & 0.807 & 0.0140 & 0.997 & 0.0292 & 0.501 & 0.0462 & 0.010 \\
\hline Tyrosine & $1 \cdot 141$ & 0.0710 & 0.366 & 0.0091 & 0.863 & 0.0644 & 0.086 & 0.0054 & 0.030 \\
\hline \multicolumn{10}{|l|}{ Essential } \\
\hline Valine & 1.012 & 0.0306 & 0.294 & 0.0052 & 0.864 & 0.0285 & 0.055 & 0.0028 & 0.012 \\
\hline Leucine & 0.998 & 0.0351 & 0.314 & 0.0056 & 0.859 & 0.0292 & 0.078 & 0.0035 & 0.026 \\
\hline Isoleucine & 1.049 & 0.0320 & 0.346 & 0.0074 & 0.940 & 0.0306 & 0.090 & 0.0046 & 0.056 \\
\hline Threonine & 0.916 & 0.0584 & 0.279 & 0.0336 & 0.717 & 0.0234 & 0.068 & 0.0085 & 0.026 \\
\hline Phenylalanine & 0.944 & 0.0315 & 0.246 & 0.0065 & 0.817 & 0.0284 & 0.039 & 0.0038 & 0.026 \\
\hline
\end{tabular}

*Bacteria extracted from caecotrophes at the end of the experiment.

†Comparison between enrichment in bacteria and caecotrophes by ANOVA.

enrichments were much lower. For lysine the enrichment still tended to be different from the control group. Similarly, with other EAA, isotope incorporation in COLL animals was significant. This suggests a possible, although small, direct absorption of microbial AA from the gut, as observed previously in pigs (Torrallardona et al. 2003b) and man (Metges et al. 1999), although not in non-coprophagic rats (Torrallardona et al. 1996b).

Direct absorption of microbial lysine in rabbits might occur from the ileum as microbial activity has been suggested within this part of the digestive tract (Gidenne et al. 1998; Carabaño et al. 2001). Nevertheless, the concentration of volatile fatty acids, indicators of microbial fermentation, is small at the ileum of rabbits (Vernay, 1987), although higher than in the duodenum or jejunum, when compared with the caecum. Therefore, absorption of microbial AA from the small intestine is probably very low or non-existent. Alternatively, some hindgut absorption has been

Table 6. Dietary and microbial contribution through caecotrophy $\left(\mathrm{M}_{\text {lys }}(\mathrm{Cec})\right)$ to body lysine, and absorption of dietary $\left(\mathrm{D}_{\text {lysA }}\right)$ and microbial lysine through caecotrophy $\left(\mathrm{M}_{\text {lysA }}\right)$

\begin{tabular}{llllll}
\hline & \multicolumn{2}{c}{$\begin{array}{c}\text { Contribution to tissue } \\
\text { lysine }\end{array}$} & & \multicolumn{2}{c}{$\begin{array}{c}\text { Lysine absorption } \\
(\mathrm{g} / \mathrm{d})\end{array}$} \\
\cline { 2 - 3 } \cline { 5 - 6 } Rabbit & Diet & $\mathrm{M}_{\text {lys }}(\mathrm{Cec})$ & & $\mathrm{D}_{\text {lysA }}$ & $\mathrm{M}_{\text {lysA }}$ \\
\hline 1 & 0.779 & 0.213 & & 0.411 & 0.112 \\
2 & 0.775 & 0.217 & & 0.410 & 0.115 \\
3 & 0.742 & 0.250 & & 0.410 & 0.138 \\
4 & 0.778 & 0.214 & 0.404 & 0.111 \\
5 & 0.765 & 0.228 & 0.405 & 0.121 \\
6 & 0.764 & 0.229 & 0.399 & 0.120 \\
Mean & 0.767 & 0.225 & 0.406 & 0.119 \\
SE & 0.0057 & 0.0057 & 0.0018 & 0.0040
\end{tabular}

${ }^{*} M_{\text {lys }}(C e c)=\left[1-\left(\left(M_{\text {lys }}(\operatorname{lnt}) / M_{\text {lys }}(T o t)\right)\right] \times M_{\text {lys }}(T o t)\right.$, where $M_{\text {lys }}(T o t)$ is the total microbial contribution, and $\mathrm{M}_{\mathrm{lys}}$ (Int) the microbial contribution from direct intestinal absorption (estimated as 0.0076 ). Microbial contributions were estimated by the ratio of $\left[{ }^{15} \mathrm{~N}\right] \mathrm{lysine}$ enrichment in liver and bacteria in animals receiving a labelled diet without $\left(\mathrm{M}_{\mathrm{lys}}(\mathrm{Tot})\right)$ or with a neck collar to avoid caecotrophy $\left(\mathrm{M}_{\mathrm{lys}}(\mathrm{Int})\right)$. suggested in pigs (Niyama et al. 1979), horses (Slade et al. 1971) and man (Jackson, 1995), as well as in rabbits (Marty \& Raynaud, 1965; Marty, 1973), but the direct incorporation from caecotrophes across the caecal wall remains controversial (Metges, 2000). In the current study, the average contribution of microbes to total lysine supply via direct intestinal absorption is very low at $0.8 \%$ compared with $22.5 \%$ through caecotrophy, i.e. $97 \%$ of bacterial lysine supply is from ingestion of caecotrophes.

Most non-essential AA, except tyrosine and proline, show high enrichments in the liver of COLL animals. This labelling occurs through two routes: synthesis by gut bacteria and subsequent absorption, or synthesis by host tissues through transamination with other AA or amination via ammonia. Therefore, we can estimate the contribution of caecotrophy in the same way as for lysine assuming that transamination and amination processes will occur in the same extent in both animal groups. A similar concept can be adopted for other EAA. By this approach most AA, except glycine and proline, give contributions $(0.21-0.27)$ from caecotrophy similar to the value obtained with lysine $(0 \cdot 23)$, which strengthens the consistency of our results. Threonine, like lysine, is not considered to undergo transamination (Adamson \& Fischer, 1971; Bender, 1985) and so can be compared directly. Indeed, threonine also gave a similar contribution of caecotrophy (0.23 (SE 0.030)) but there were some technical difficulties in chromatographic purity for some samples. This technical problem may account for the relatively higher enrichment, compared with lysine, in livers from COLL animals.

Overall, our findings show that caecotrophagic animals were able to incorporate ${ }^{15} \mathrm{~N}$ to a greater extent than non-caecotrophagic animals into body lysine and that direct microbial lysine absorption contributes only a very small proportion of the absorbed lysine, with most arising through caecotrophy.

\section{Level of microbial protein absorption}

Microbial lysine absorption was estimated by assuming a true ileal digestibility of food lysine of $0 \cdot 8$, based on the analysis of 
true digestibility of the ingredients of rabbit diets described by Carabaño et al. (2000): 0.88 for barley, 0.69 for sugarbeet pulp, and assuming from their results a coefficient of 0.70 and 0.95 for grass hay and soyabean meal, respectively.

In this regard it is necessary to point out that determining the true ileal digestibility of AA is not easy (Williams, 1995), particularly in rabbits where an important residue of bacterial $\mathrm{N}$ comes out from the ileum together with the endogenous fraction (Carabaño et al. 2000). Although a close agreement between true ileal digestible lysine and lysine retention has been reported in several pig studies (Tanksley \& Knabe, 1984; Leibholz, 1985), we are aware that availability is not fully equivalent to true ileal digestibility (Batterman, 1992) since digestible lysine could be absorbed in forms inefficiently used. Thus in heatdamaged proteins ileal digestibility overestimates lysine availability for growing pigs (Batterman et al. 1990). Unavailability of absorbed lysine might affect calculation of microbial lysine incorporation, but the existence of lysine as an absorbable but non-available form has never been described for soyabean protein.

Finally, we were able to measure the contribution of microbes through caecotrophy to total protein intake. We determined (Table 3) the level of lysine in dietary and bacterial protein. From microbial contribution to tissue lysine, the estimated contribution of caecotrophy to total protein intake is $15 \%$.

In conclusion, the present experiment confirms the importance of the caecum in rabbit protein metabolism and the supply of essential nutrients which otherwise may limit animal performance. These results together with those on the effect of diet on soft faeces production (Belenguer et al. 2002) underline the importance of considering the dual origin of essential nutrients in rabbit nutrition. As far as protein supply is concerned, feeding costs may be saved by considering in the formulation of diets the microbial contribution (based on diet characteristics) in addition to the dietary supply of AA.

\section{Acknowledgements}

The work was financed by Agribrands Europe España SA, Barcelona, Spain and the Spanish Ministry of Science through Projects PTR 95/0405-OP and PB98-01 601. A. B. was supported by a fellowship from the Spanish Science and Technology Ministry. The authors gratefully acknowledge Dr Gerald Lobley for his helpful assistance and suggestions in the preparation of the manuscript. Thanks are given to Animal Nutrition Department (Estación experimental del Zaidín, CSIC, Granada) for AA analysis and to the Servicio de Apoyo a la Investigación (Universidad de Zaragoza) for care of animals.

\section{References}

Adamson I \& Fischer H (1971) The amino acid requirement of the growing rabbit: qualitative needs. Nutr Rep Int 4, 59-64.

Batterman ES (1992) Availability and utilization of amino acids for growing pigs. Nutr Res Rev 5, 1-18.

Batterman ES, Andersen LM, Baigent DR, Darnell RE \& Taverner MR (1990) A comparison of the availability and ileal digestibility of lysine in cottonseed and soya bean meal for grower/finisher pigs. $\mathrm{Br}$ J Nutr 64, 663-667.

Belenguer A, Balcells J, Fondevila M \& Torre C (2002) Caecotrophes intake in growing rabbits estimated either from urinary excretion of purine derivatives or from direct measurement using animals provided with a neck collar: effect of type and level of dietary carbohydrate. Anim Sci 74, 135-144.

Bender DA (1985) Amino Acid Metabolism. Chichester: John Wiley \& Sons.

Carabaño R, de Blas JC \& García AI (2000) Recent advances in nitrogen nutrition in rabbits. World Rabbit Sci 8, Suppl. 1, 15-28.

Carabaño R, García J \& de Blas JC (2001) Effect of fibre source on ileal apparent digestibility of non-starch polysaccharides in rabbits. Anim Sci 72, 343-350.

Cheeke PR (1987) Rabbit Feeding and Nutrition. Corvallis, OR: Academic Press, Inc.

Cohen SA, Meys M \& Tarvin TL (1989) The Pico-Tag Method. A Manual of Advanced Techniques for Amino Acid Analysis. Bedford, MA: Millipore Corporation.

Emaldi O, Crociani F \& Matteuzzi D (1979) A note on the total viable counts and selective enumeration of anaerobic bacteria in the caecal content, soft and hard faeces of rabbit. J Appl Bacteriol 46, $169-172$.

Forsythe SJ \& Parker DS (1985) Ammonia-nitrogen turnover in the rabbit caecum and exchange with plasma urea-N. $B r J$ Nutr 54, $285-292$.

Fraga MJ (1998) Protein digestion. In The Nutrition of the Rabbit, pp. 39-54 [C de Blas and J Wiseman, editors]. Wallingford: CABI Publishing.

Gidenne T, Carabaño R, García J \& de Blas C (1998) Fibre digestion. In The Nutrition of the Rabbit, pp. 69-88 [C de Blas and J Wiseman, editors]. Wallingford: CABI Publishing.

Hörnicke H (1981) Utilization of caecal digesta by caecotrophy (soft faeces ingestion) in the rabbit. Livest Prod Sci 8, 361-366.

Jackson A (1995) Salvage of urea-nitrogen and protein requirements. Proc Nutr Soc 54, 535-547.

Jehl N, Gidenne T \& Le Roux JF (1996) Measurement of the bacterial fibrolytic activity in the caecum and in the soft faeces of the rabbit. In Proceedings of the 6th World Rabbit Congress, vol. 1. pp. 199-203 [F Lebas, editor]. Toulouse: World Rabbit Science Association.

Leibholz J (1985) An evaluation of total digestible lysine as a predictor of lysine availability in protein concentrates in young pigs. Br J Nutr 53, 615-624.

Lobley GE, Milne V, Lovie JM, Reeds PJ \& Pennie K (1980) Whole body and tissue protein synthesis in cattle. Br J Nutr 43, 491-502.

Marty J (1973) (Sur le role de la paroi: caecale du lapin dans la regulation de l'aminoacidemie). Role of the cecal wall in the regulation of the amino acid blood level in rabbits. C R Acad Sci Hebd Seances Acad Sci D 276, 569-571.

Marty J \& Raynaud P (1965) (Aminacidemie caecale du lapin. Recherches sur l'absorption de la valine et de la leucine). Cecal blood amino acids in rabbits. Research on the absorption of valine and leucine. Arch Sci Physiol (Paris) 19, 321-330.

Metges CC (2000) Contribution of microbial amino acids to amino acid homeostasis of the host. J Nutr 130, Suppl., 1857S-1864S.

Metges CC, El-Khoury AE, Henneman L, Petzke KJ, Grant I, Bedri S, Pereira PP, Ajami AM, Fuller MF \& Young VR (1999) Availability of intestinal microbial lysine for whole body lysine homeostasis in human subjects. Am J Physiol 277, E597-E607.

Minato H \& Suto T (1978) Technique for fractionation of bacteria in rumen microbial ecosystem: II. Attachment of bacteria isolated from bovine rumen to cellulose powder in vitro and elution of bacteria attached therefrom. J Gen Appl Microbiol 24, $1-16$.

Nicholas GA, Lobley GE \& Harris CI (1977) Use of the constant infusion technique for measuring rates of protein synthesis in the New Zealand White rabbit. Br J Nutr 38, 1-17.

Niyama M, Deguchi E, Kagota K \& Namioka S (1979) Appearance of ${ }^{15} \mathrm{~N}$-labeled intestinal microbial amino acids in the venous blood of the pig colon. Am J Vet Res 40, 716-718. 
Slade LM, Bishop R, Morris JG \& Robinson DW (1971) Digestion and the absorption of ${ }^{15} \mathrm{~N}$-labelled microbial protein in the large intestine of the horse. Br Vet $J$ 127, xi-xiii.

Tanksley TD \& Knabe DA (1984) Ileal digestibility of amino acids in pigs feeds and their use in formulating diets. In Recent Advances in Animal Nutrition 1984, pp. 75-95 [W Haresign and DJA Cole, editors]. London: Butterworths.

Torrallardona D, Harris CI, Coates ME \& Fuller MF (1996a) Microbial amino acid synthesis and utilisation in rats: incorporation of ${ }^{15} \mathrm{~N}$ from ${ }^{15} \mathrm{NH}_{4} \mathrm{Cl}$ into lysine in the tissues of germ-free and conventional rats. Br J Nutr 76, 689-700.

Torrallardona D, Harris CI \& Fuller MF (1996b) Microbial amino acid synthesis and utilisation in rats: the role of coprophagy. $\mathrm{Br} J \mathrm{Nutr}$ 76, 701-709.
Torrallardona D, Harris CI \& Fuller MF (2003a) Lysine synthesized by the gastrointestinal microflora of pigs is absorbed, mostly in the small intestine. Am J Physiol 284, E1177-E1180.

Torrallardona D, Harris CI \& Fuller MF (2003b) Pigs' gastrointestinal microflora provide them with essential amino acids. J Nutr 133, $1127-1131$.

Van Soest PJ, Robertson JB \& Lewis RA (1991) Methods for dietary fiber, neutral detergent fiber and non starch polysaccharides in relation to animal nutrition. J Dairy Sci 74, 3583-3597.

Vernay M (1987) Origin and utilization of volatile fatty acids and lactate in the rabbit: influence of the faecal excretion pattern. Br J Nutr 57, $371-381$.

Williams PEV (1995) Digestible amino acids for non-ruminants animals: theory and recent challenges. Anim Feed Sci Technol 53, 173-187. 